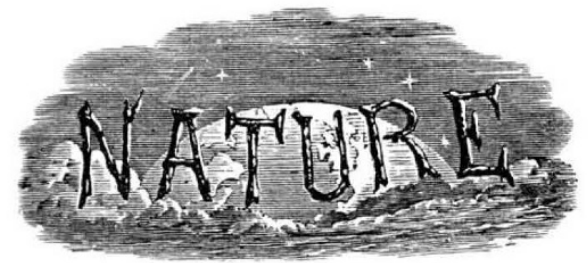

SATURDAY, FEBRUARY 9, I935

No. 3406

CONTENTS

The Planting of Hardwood Trees

The Concept of Time in Physics. By Prof. Herbert Dingle

Sex and Culture. By Prof. Morris Ginsberg.

Mineral Resources of the French Colonies

Short Notices

Television in Great Britain 209

Social and Industrial Aspects of Scientific Research 2II Obituary:

Dr. F. A. Dixey, F.R.S. By Prof. G. D. Hale Carpenter

Sir William Slingo. By A. S. A.

Dr. John Howard

News and Views

Letters to the Editor :

Light of the Night Sky.--Prof. Joseph Kaplan

Zero Point Energy and Physical Properties of $\mathrm{H}_{2} \mathrm{O}$ and $\mathrm{D}_{2} \mathrm{O}$.- J. D. Bernal and G. Tamm .

The Pair Bond Theory of Valency.-Dr. H. Lessheim and Prof. R. Samuel

Reafforestation of Forest Trees in Great Britain. -Alexander L. Howard $\dot{0} \cdot \dot{ }$ Interpretation of Animal Behaviour.-J. A. Lauwerys; The Writer of the Article . .

Effect of Ultra-Centrifuging on the Cells of the Root-Tip of the Bean.-Dr, H. W. Beams and

R. L. King
Some Recent Atomic Weight Determinations.-

Dr. W. Cawood ${ }^{\circ}$ on the Absorption of Crystals in the Infra-Red.-Dr. M. Blackman Surface Tension of Urine during the Menstrual Cycle.-C. F. Selous and P. W. Perryman .

Biological Formation of Ascorbic Acid.-Dr.

B. C. Guha and A. R. Ghosh $\dot{\text { Male Sex }}$
Alleged Estrogenic Activity of the Mal Hormone.-F. L. Warren

Mr. Mallock's Electrical Calculating Machine.Dr. A. C. Aitken

Research Items.

Pittsburgh Meeting of the American Association. By Dr. Henry B. Ward . . . . .

Science and the Newspaper Press in the United States

University and Educational Intelligence

Science News a Century Ago

Societies and Academies

Forthcoming Events

Official Publications Received

SUPPLEMENT:

The Atmospheres of the Planets. By Dr. Henry Norris Russell

Editorial and Publishing Offices :

MACMILLAN \& CO., LTD.

ST. MARTIN'S STREET, LONDON, W.C.2

Telephone Number : WHI TEHALL 883I

Telegraphic Address : PHUSIS, LESQUARE, LONDON

\section{The Planting of Hardwood Trees}

RECENT correspondence in the Press, to which

Mr. Alexander Howard refers in a letter on p. 231 of this issue, has directed attention to the alarming rate at which hardwood trees, whether isolated or in hedgerows, woodlands or otherwise, are being felled in many parts of Britain without any attempt at replanting. Various reasons for this state of affairs might be given, including high taxation, which has forced landowners to realise every possible tree in an endeavour to retain possession of their property, the general depression, the break-up of estates, the high level of wages, the remoteness of prospective yields and uncertainty as to the future, which prevent landowners from sinking capital in long-term investments such as plantations. On the other hand, it should be mentioned that recent legislation provides a large measure of relief in regard to taxation and death duties; among other things, for purposes of probate the value of woodlands is excluded from the total value of an estate, and a landowner therefore stands to benefit his estate by storing up capital in the form of growing timber.

It will be convenient if we approach this question from two points of view, the æsthetic or sentimental on one hand and the economic or utilitarian on the other. These are not necessarily antagonistic. Opinions on the æsthetic value of different classes of trees are governed so much by personal taste or sentiment that agreement on the subject can scarcely be expected. But misdirected sentiment has been responsible for some confusion of ideas. Some writers advocate the wider use of our 'native hardwoods', but include among them various introduced species, such as the 'common' elm, the sycamore, the lime, the walnut and others. At the same time, they have condemned the use of conifers, partly for æsthetic reasons and partly because all our coniferous timber trees except the Scots pine are exotics. This attitude is scarcely reasonable, for among the conifers are to be found some of the most beautiful and interesting trees in the world. Let it be admitted, therefore, that conifers, when used with discretion, have their æsthetic value as well as hardwoods. But when we find, as we now do, that the hardwood trees which have been the glory of English scenery in the past are being extensively felled, and if replaced at all are being replaced mainly by conifers, it is time to call a halt. Here we touch the economic and utilitarian side of the question. 
So far as requirements in bulk are concerned, coniferous timbers (softwoods) are of much more importance than hardwoods. They constitute about eighty per cent of the world's consumption of sawn timber, and are used in large quantities for pitprops, telegraph and other poles, paperpulp and other purposes. Owing to the depletion of the world's timber resources, a serious shortage of softwoods within a measurable period of time is predicted, though hardwoods in general will not be affected to anything like the same extent. It is partly for this reason that in the programme of State afforestation proposed by the Acland Committee of 1916-17, and now being carried out by the Forestry Commission, the area to be afforested with conifers was estimated at $1,770,000$ acres and that required for hardwoods at only 100,000 acres, or about $5 \cdot 3$ per cent of the total. This policy has been modified recently in favour of an increased use of hardwoods for afforestation in localities suitable for them, and actually more than six per cent of the total area afforested to date has been planted with hardwoods. The planting of hardwoods, however, is restricted by the fact that the price to be paid by the Commissioners for land is fixed at a comparatively low figure. This means that much of the land acquired is too poor for the cultivation of the more valuable hardwoods, and is fit only for the less exacting conifers. Nevertheless, in areas planted with conifers steps are being taken, on æsthetic as well as on sylvicultural and protective grounds, to introduce broad-leaved trees along the sides of roads, and even within the plantations.

That the private landowner should replace the previously existing hardwood crops by coniferous plantations is not altogether surprising. The latter may possibly yield returns within the lifetime of himself or his heir, but there is small hope of this in the case of the former, if we exclude such shortrotation crops as chestnut coppice and the like. Leaving asthetic and sentimental considerations out of account, therefore, are there any economic or technical reasons why hardwoods should continue to hold an important place in British forestry? The answer to this question is a decided affirmative. Although the total consumption is considerably less in the case of hardwoods than of softwoods, there are many special purposes for which hardwoods, and definite species of hardwoods, are alone suitable; and it is important that future supplies of such woods should be ensured. Again, extensive afforestation with introduced conifers is attended with considerable risk from insect pests and fungus diseases, particularly in a country like England, the natural forest vegetation of which consists predominantly of broad-leaved trees. France is now learning this to her cost in the Seine valley, where forests of introduced Scots pine, created on a large scale early last century, are being decimated by fungus diseases. A generous mixture of hardwoods in coniferous crops is one of the best safeguards against such a calamity, and it has the further advantage of reducing the risks from fire and storms as well as of maintaining the fertility of the soil, and with it the health and vigour of the crop. To summarise the position, although there are strong economic reasons for the extensive use of conifers for afforestation, there are equally strong reasons, from several points of view, for paying special attention to the cultivation of hardwood trees.

When we come to consider the question of preventing the destruction of existing woodlands and trees, preserving the beauty of the countryside, and ensuring future supplies of hardwood timber, we are faced with problems of a somewhat complicated nature. State afforestation may be expected to continue, possibly on a more extended scale, and it is hoped that hardwoods will receive due attention. A great deal more might be done by corporations and municipalities to acquire, and even create, woodland areas within easy reach of towns; the numerous town forests in France, Germany, Austria and other Continental countries, which are so great a boon to the town-dwellers, serve as an example of what might be done in Britain. It is when we consider the question of private estates that the problem presents special difficulties. In some Continental countries, stringent laws exist for ensuring the proper management of private forests and the regeneration of all areas felled. There is much to be said for introducing legislation designed to ensure the regeneration of felled areas, and to improve the admittedly faulty management of so many private woodlands in Britain.

On the Continent, legislation of the kind indicated applies generally to properties with a stated minimum woodland area, and its object is primarily economic. It would not cover the case of individual or hedgerow trees, or that of the numerous small copses, belts of trees, and woodland dells which are such a feature of the English countryside. The Irish Free State, by the Forestry Act of 1928 , is making serious efforts to restrict the felling of trees on 
private property. In Great Britain similar restrictions, however well-meaning, might prove difficult and costly to apply in practice; better results would probably be achieved, at less cost, by a policy which would give landowners more encouragement to maintain the beauty of their estates as their forbears did. Something might be done by means of State aid to bodies such as the National Trust, for the acquisition of small woodland areas or park lands to be preserved primarily for æsthetic reasons. Last, but not least, there is great need for educating the British public to respect trees and woodlands, which suffer from acts of vandalism unheard of in those European countries in which the 'tree sense' or 'forest conscience' is more fully developed: with the help of schools, the rising generation, at any rate, might be brought up to realise that trees and woods are a heritage which should be valued and respected.

\section{Reviews}

The Concept of Time in Physics

The Serial Universe. By J. W. Dunne. Pp. 242. (London : Faber and Faber, Ltd., 1934.) 10s.6d. net.

TN 1927, Mr. Dunne published a book recording dream experiences which seemed to indicate prevision of future events. Being a thorough Copernican, he scorned the idea of personal peculiarity and began to examine the concept of time. His conclusions were so strange that stronger observational evidence was generally demanded; yet it was clear even then that the theory was grounded on the general nature of thought rather than the particular data of experience. The issue is now eleared. In his new book, Mr. Dunne applies his theory to the facts of modern physics instead of to dreams. Those facts are numerous and authentic enough: we can no longer evade the challenge by demanding further evidence.

Mr. Dunne's presentation of his case deserves the highest praise. The book is a model of clear thought and expression, and the style excites interest to the point of fascination without sacrifice of critical attention. A mathematical physicist might have expressed a few points differently, but that is immaterial. Whatever verdict awaits the ideas, their cause could scarcely have found a better advocate.

The theory starts from the idea of a regression, that is, a series of terms of which each, after the first, demands the next, and which therefore extends to infinity. An artist paints a picture of the universe. But he is a part of the universe, so the picture must include a picture of himself painting the same picture-which, being the same picture, must itself include him; and so on ad infinitum. This is a type of all regressions. The first term (the universe) alone does not require the remainder, but when the artist in the second term enters the picture, there is no escape; we are doomed to follow the succession of artists and pictures to the bitter endlessness.
Consider, now, an objective world, $A$, described from the indications of independent instruments, $B$. The instruments observe now, but we define the world as extended in time, and from memory and calculation represent it as a static fourdimensional thing, along the time dimension of which our instruments move from past to future. The instruments, however, are not inherently independent of $A$, being so regarded only when they are observing it : a wider view of $A$ shows it as including $B$. But that puts the artist into the picture. The sequel is inevitable.

This process is linked with the notion of time. The world, $A$, extends through time, $T_{1}$, along which the instrument moves, making contact only at the 'now'. But such a movement requires another time, $T_{2}$ : the first- $-\mathrm{a}$ static dimension through which $A$ extends-cannot give meaning to the motion of $B$ along itself. When we retreat a stage and contemplate, as a single system, $A$ with its $T_{1}$ and $B$ moving in $T_{2}$ to observe $A$, a third 'time' becomes necessary. Thus we regressindefinitely.

At each step the abandoned time becomes a new dimension of space - of a continuum, that is, which has as many dimensions (including the three dimensions of 'ordinary' space) as there are possibilities of independent continuous variation of the system located in it. Thus we normally imagine a three-dimensional space world changing in time. When we consider its history, we petrify its eternal progress along $T_{1}$ into an $A$ having what is equivalent to infinite space extension in that dimension, and transfer the dynamic element of time to $T_{2}$. When we withdraw to watch $B$ observing $A, T_{2}$ in turn is fixed, its spirit flying out along $T_{3}$. At the next step, the Gorgon's head is shown to $T_{3}$, and the vital spark escapes along $T_{4}$. Whenever $T_{n}$ is time, there are $n+2$ dimensions of space-the familiar three plus the $n-1$ quiescent eternities.

We can picture the process as a mad pursuit 